\title{
The Effect of Local Revenue on Local Expenditures in East Kalimantan Province, Indonesia
}

\author{
La Ode Hasiara ${ }^{1}$, Amiril Azizah $^{2}$ \\ \{hasiara@polnes.ac.id $\left.{ }^{1}\right\}$ \\ Department of Accounting, Samarinda State Polytechnic, Indonesia ${ }^{1}$ \\ Department of Marketing Management, Samarinda State Polytechnic, Indonesia ${ }^{2}$
}

\begin{abstract}
This research aim is to know, test, and analyzing the effect of local revenue and matching grant (general allocation fund, special allocation fund, and profit-sharing fund) on local expenditure at districts/cities in East Kalimantan province. This research uses quantitative methods with documentary data from the realization of district/city APBD in East Kalimantan Province. The analytical tool is the Multiple Linear Regression The study's findings indicate that local revenue has a positive and statistically significant effect on local expenditure, that general allocation funds have a positive and statistically significant effect on local expenditure, that special allocation funds have no effect on local expenditure, and that revenue sharing funds have a positive and statistically significant effect on local expenditure. Local Revenue (PAD), General Allocation Fund (DAU), Special Allocation Fund (DAK), and Profit-Sharing Fund (DBH) simultaneously have a positive and significant effect on Local expenditure at Districts / Cities in East Kalimantan Province for 2014-2018 period. The result indicates that R2 is 0.905 or $90.5 \%$, it means the effect on local expenditure is $90.5 \%$, while the remaining $9.5 \%$ is affected by other variables outside this study.
\end{abstract}

Keywords: Local revenue, general allocation fund, special allocation fund, profit sharing fund, local expenditure

\section{Introduction}

This research is interested to examine some districts in East Kalimantan Province that do not receive the General Allocation Fund. One of them is Kutai Kartanegara district. This is a sign that the district is rich. However, in reality, the construction of road infrastructure is very worrying, because there are still many roads full of holes. This is something that contrary to reality [1]. This condition strengthens the demands for transparency and accountability aspects [2]. These two aspects are important in management of state and regional finances. It becomes the trigger for the transition process from a deconcentration system to a decentralization system called autonomy [3].

The state revenue from profit-sharing funds is set at $90 \%$, with the share if $16.2 \%$ for the province and $64.8 \%$ for the districts/cities. The collection fee of $9 \%$ and $10 \%$ is allocated to all regencies and cities, while the land and building tax is classified as $90 \%$ for regions [4]. 


\section{Literature Review}

Law Number 33 of 2004 [5] on the Financial Balance of the Central Government and Local Governments stated that local revenue was collected by regions pursuant to Regional Regulations. Meanwhile, local revenue recognizes local government rights as an addition to asset value. The government has the right to obtain regional revenue as an addition to funds equity in the appropriate fiscal year.

\subsection{Dependent variable (Y)}

The dependent variable is influenced by the independent variable [6]. Local expenditure is the dependent variable in this research. Domestic Affairs Minister Regulation No. 13 of 2011 [7] on Regional Financial Management mentioned that local expenditures comprise all expenditures from regional general treasury accounts that diminish fund equity, regional liabilities in a fiscal year, and payment was not reclaimed by regions [8].

\subsection{Local revenue $(\mathrm{PAD})=\mathrm{X} 1$}

Local revenue is defined in Law Number 23 of 2014 [5] as funds collected by a region in line with regional laws and statutory requirements [9].

\subsection{General allocation fund $(\mathrm{DAU})=\mathrm{X} 2$}

Government Regulation no. 55 the year 2005 [4] on General Allocation Fund (DAU) stated that General Allocation Fund is a fund from APBN which is allocated with the aim to equalize inter-regional finance to finance expenditure needs in the context of decentralization implementation [10].

\subsection{Special Allocation Fund $(\mathrm{DAK})=\mathrm{X3}$}

According to Law No. 23 of 2014 [5], the Special Allocation Fund (DAK) is a fund derived from APBN earnings distributed to certain areas with the purpose of facilitating the fund's use for special activities such as regional affairs and national priorities [11].

\subsection{Profit-sharing fund $(\mathrm{DBH})=\mathrm{X} 4$}

Article 1 paragraph 49 of Law Number 23 of 2014 [5] [12] on Local Government stated that the Profit-Sharing Fund, hereinafter abbreviated as DBH, is funds derived from certain APBN revenues that are allocated to region contributors based on a certain percentage with the purpose of reducing financial capacity imbalances between the Central and Local Governments. Article 1 paragraph 47 of 2004's Law No. 33 on Local Government stated that DBH is supported by APBN, which are provided with the goal of balancing interregional financing in order to pay spending demands associated with decentralization implementation [13]. The distribution of the DBH money is shown in Table 1. 
Table 1. Distribution of tax sharing funds

\begin{tabular}{llcccccc}
\hline & & \multicolumn{3}{c}{ DBH Tax } & \multicolumn{3}{c}{ DBH Proportion of Local Tax } \\
\cline { 3 - 7 } No & Type & Government & Local & Province & Contributor & $\begin{array}{c}\text { Other District/ City Collection } \\
\text { in Province }\end{array}$ & Wage \\
\hline 1 & PBB & $10 \%$ & $90 \%$ & $16,2 \%$ & $64,8 \%$ & - & $9 \%$ \\
2 & BPHTP & $20 \%$ & $80 \%$ & $16 \%$ & $64 \%$ & - & - \\
3 & PPH & $80 \%$ & $20 \%$ & $8 \%$ & - & $12 \%$ & - \\
\hline
\end{tabular}

Source: Government regulation no. 55 the year 2005

DBH from taxes is the local portion derived from land and building tax revenue. It consists of Cost of Land Acquisition and Building Rights, Income Tax in Article 25 and Article 29 Domestic Individual Taxpayer, and Income Tax in Article 21. Distribution of Oil and Gas Balancing Funds to regions is done by the basic assumption that the price of petroleum does not exceed $130 \%$ of stipulations in the current year of APBN [14], [15]. The difference in state revenue from oil and natural gas as a result of excess is allocated using the DAU formula. Based on this explanation, the research framework for the relationship between independent and dependent variables are shown in Figure 1.

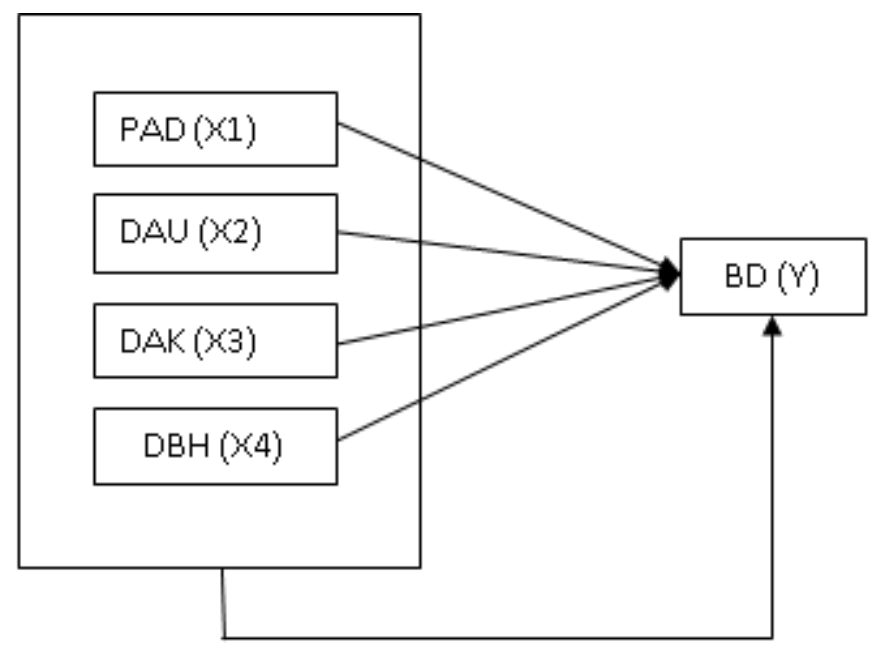

Fig 1. Research Conceptual Framework

\subsection{Hypothesis}

Based on the description of the theory, the research hypothesis can be formulated as General Allocation Fund (DAU), Local Revenue (PAD), Profit Sharing Fund (DBH), Special Allocation Fund (DAK), which all have a positive and significant effect on Local expenditure. 


\section{Method}

The operational definition is a phrase that serves to explain the variables under investigation. The purpose of this study is to ascertain the impact of DAD, DAU, DAK, DBH on local spending in Samarinda City. The population is defined as a segment of the population made up of objects/subjects with specific features and attributes chosen by the researcher for the purpose of data collection. [4]. This study enrolled residents of all districts and cities in East Kalimantan Province.

The documentation is used to compile data for this investigation. This approach is used to collect data on PAD, DAU, DAK, and DBH in East Kalimantan. The following data analysis approaches were used in this investigation. To gain an overview of the study sample, descriptive statistical analysis is utilized. It contains the mean, mode, maximum, median, and lowest values for each variable in the research model [16]. Many linear regression is a statistical approach for examining the connection between multiple independent variables and a single dependent variable.. The following are the equation models for multiple regression analysis.

$$
\mathrm{Y}=\mathrm{a}+\mathrm{b} 1 \mathrm{X} 1+\mathrm{b} 2 \mathrm{X} 2+\mathrm{b} 3 \mathrm{X} 3+\mathrm{b} 4 \mathrm{X} 4+\mathrm{e}
$$

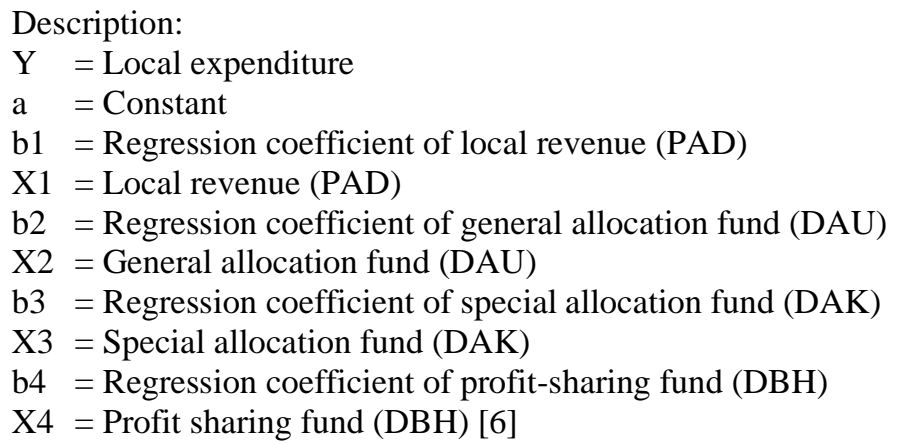

\section{Results and Discussion}

Topographic circumstances have a significant impact on a commodity's cultivation prospects, water potential and availability, hydrological dynamics, and susceptibility to erosion. According to the topography, the majority of the land area (43.35 percent) is within the $40 \%$ slope, while 43.22 percent is located between 100 and 1000 meters above sea level. As a result, land use in East Kalimantan Province must take into account the land's peculiarities. East Kalimantan Province is divided into ten districts/cities: (1) Berau, (2) West Kutai, (3) Kutai Kartanegara, (4) East Kutai, (5) Paser, (6) North Penajam Paser, (7) Mahakam Ulu, (8) Balikpapan, (9) Bontang, and (10) Samarinda. Local expenditure is the dependent variable, whereas PAD, DAU, DAK, DBH are the independent variables. Table 2 summarizes the data. 
Table 2. Descriptive statistics results

\begin{tabular}{lccccccc}
\hline & N & Range & Minimum & Maximum & Mean & Std. Deviation & Variance \\
\hline PAD & 50 & 1334713 & 3723 & 1338436 & 262109.26 & 242819.478 & 58961298700 \\
DAU & 50 & 560467 & 104683 & 665150 & 389625.66 & 172756.311 & 29844743060 \\
DAK & 50 & 365009 & 1575 & 366584 & 97540.72 & 85594.247 & 7326375166 \\
DBH & 50 & 4819975 & 252167 & 5072142 & 1046427.76 & 922720.762 & 851413604300 \\
BD & 50 & 6289590 & 485783 & 6775373 & 2271950.02 & 1222828.633 & 1495309866000 \\
Valid N & 50 & & & & & &
\end{tabular}

Source: Secondary data processed, 2020

Table 2 shows that Local expenditure variable (Y) has the lowest value of 485,783, highest value of $6,775,373$, range value of $6,289,590$, average value of 2,271,950.02 and standard deviation value of $1,222,828,633$. The Local revenue variable (X1) has the lowest value of 3,723 , highest value of $1,338,436$, range value of $1,334,713$, average value of $262,109.26$ and standard deviation value is $242,819,478$. The General Allocation Fund (X2) variable has the lowest value of 104,683 . The highest value of 665,150 . range value of 560,467. The average value of 389,625 . and the standard deviation value of 172,756,311. The Special Allocation Fund (X3) variable has the lowest value of 1,575, highest value of 366,584. range value of 365,009, average value of $97,540.72$ and standard deviation value of $85,594,247$. The Profit-Sharing Fund (X4) variable has the lowest value of 252,167, highest value of 5,072,142, range value of $4,819,975$, average value of $1,046,427.76$ and standard deviation value of $922,720,762$.

\subsection{Classic assumption test}

Normality, Multicollinearity, Heteroskedasticity, and Autocorrelation are all forms of classical assumption tests. To begin, the Kolmogorov-Smirnov Normality Test is included in the classical hypothesis test. The normality test indicates that the data in this study have a normal distribution. The dots that encircle the diagonal lines up and down indicate this. Additionally, the Kolmogorov-Smirnov test value is $0.20>0.05$, indicating a substantial difference. It is well established that the residual value follows a normal distribution. Furthermore. The Multicollinearity test is used to determine the relationship between independent variables. No connection exists between the dependent and independent variables in a good regression model. Table 3 summarizes the findings of the multicollinearity test on the research variables.

Table 3. Multicollinearity test results

\begin{tabular}{|c|c|c|c|c|c|c|c|c|}
\hline \multirow{2}{*}{\multicolumn{2}{|c|}{ Model }} & \multicolumn{2}{|c|}{ Unstandardized } & \multirow{2}{*}{$\frac{\text { Standardized }}{\text { Beta }}$} & \multirow[b]{2}{*}{$\mathrm{t}$} & \multirow[b]{2}{*}{ Sig. } & \multirow{2}{*}{$\begin{array}{c}\text { Collinearity } \mathrm{t} \\
\text { Tolerance }\end{array}$} & \multirow{2}{*}{$\begin{array}{l}\text { Statistic } \\
\text { VIF }\end{array}$} \\
\hline & & $\mathrm{B}$ & Std. Error & & & & & \\
\hline 1 & (Constant) & -28644.968 & 178263.150 & & -.161 & .873 & & \\
\hline & PAD & .743 & .224 & .148 & 3.314 & .002 & .980 & 1.020 \\
\hline & DAU & 1.937 & .335 & .274 & 5.773 & .000 & .865 & 1.156 \\
\hline & DAK & -.208 & .644 & -.015 & -.324 & .748 & .956 & 1.046 \\
\hline & $\mathrm{DBH}$ & 1.311 & .063 & .989 & 20.810 & .000 & .860 & 1.163 \\
\hline
\end{tabular}

a. Dependent variable: Local expenditure

Source: Secondary data processed, 2020

Third, Table 3 shows that tolerance value for Local Revenue (X1) is $0.980>0.10$, General Allocation Fund (X2) is 0.865>0.10, Special Allocation Fund (X3) is 0.956>0.10, and Fund 
Profit Sharing (X4) is $0.860>0.10$. It can be seen that all tolerance values of each variable are not more than 0.10 so that there is no indication of any multicollinearity symptoms. The VIF value of Local Own Revenue (X1) is $1.020<10$, General Allocation Fund (X2) is $1.156<10$, Special Allocation Fund (X3) is $1.046<10$, and Profit-Sharing Fund (X4) is $1.163<10$. It can be seen that all VIF values of each variable are less than 10 so that there is no multicollinearity symptom. Fourth, the autocorrelation test is used to assess whether or not the multiple linear regression model has a confounding error in period $t$ that is related to an error in the prior $t$ period. The Durbin-Watson test is employed in Table 4 to determine autocorrelation.

Table 4. Durbin-Watson autocorrelation test results

\begin{tabular}{lccccc}
\hline Model & R & R Square & $\begin{array}{c}\text { Adjusted R } \\
\text { Square }\end{array}$ & $\begin{array}{c}\text { Std.Error of the } \\
\text { Estimate }\end{array}$ & $\begin{array}{c}\text { Durbin- } \\
\text { Watson }\end{array}$ \\
\hline 1 & $0.955 \mathrm{a}$ & 0.923 & 0.905 & 377265.513 & 1.213 \\
\hline
\end{tabular}

a. Predictors: (Constant), DBH, PAD, DAK, DAU

b. Dependent Variable: Local Expenditure

Table 4 shows that Durbin Watson value is 1.213 , which means that Durbin Watson value $(\mathrm{DW})>-2$ and DW value <2. It means that autocorrelation does not occur [16]. Heteroscedasticity Test. The heteroscedasticity test is done with Glesjser heteroscedasticity test between the research variables, as shown in Table 5 .

Table 5. Glesjser heteroscedasticity test results.

\begin{tabular}{|c|c|c|c|c|c|c|}
\hline & \multirow[t]{2}{*}{ Model } & \multicolumn{2}{|c|}{$\begin{array}{l}\text { Unstandardized } \\
\text { Coefficients }\end{array}$} & \multirow{2}{*}{$\begin{array}{c}\text { Standardized Coefficients } \\
\text { Beta }\end{array}$} & \multirow[t]{2}{*}{$\mathbf{t}$} & \multirow[t]{2}{*}{ Sig. } \\
\hline & & B & Std.Error & & & \\
\hline \multirow[t]{5}{*}{1} & (Constant) & .973 & .585 & & 1.663 & .103 \\
\hline & PAD & .010 & .015 & .107 & $\begin{array}{c}.656 \\
-\end{array}$ & .515 \\
\hline & DAU & -.043 & .030 & -.220 & 1.422 & .162 \\
\hline & DAK & .008 & .012 & .100 & $\begin{array}{c}.660 \\
-\end{array}$ & .513 \\
\hline & DBH & -.036 & .027 & -.211 & 1.303 & .199 \\
\hline
\end{tabular}

a. Dependent variable: abs_res

Source: Secondary data processed, 2020

Table 5 shows Local Revenue has a significant value of 0.515 , General Allocation Fund has a significant value of 0.162 , Special Allocation Fund has a significant value of 0.513 , and Profit-Sharing Fund has a substantial value of 0.199 , which is more than the 0.05 threshold. It can be concluded that the regression model used to examine the influence of PAD, DAU, DAK, $\mathrm{DBH}$ on local expenditure does not exhibit issues with heteroscedasticity.

\subsection{Multiple regression test}

The coefficient of determination (R2) is used to assess a model's capacity to account for variance in independent variables. The small value of $\mathrm{R} 2$ indicates that the independent variable's capacity to influence the dependent variable is quite restricted. R2's shortcoming is that it is skewed toward the number of independent variables in the model [17]. As a result, it is advised to utilize the Adjusted R2 value for determining the optimal regression model. Adjusted 
R2 (determination coefficient) equals 0.913 . This indicates that the independent variables (X) have a 91.3 percent influence on the dependent variable (Y). Meanwhile, the remaining 8.7 percent was influenced by characteristics not included in the research. The t-test was used to determine the independent factors' partial impact on the dependent variable. The following approach may be used to locate the t table: The number of variables $X(k)$ equals four, and the amount of data / response / sample (n) equals fifty. Significance level (sig) two sides $=0.05=$ $5 \%=$ because two sides equal 0.025 . Degrees of freedom $(\mathrm{df}=\mathrm{n}-\mathrm{k}-1)$ are equal to $50-4-1=45$. The $t$ table is equal to 2.01410 (seen from T table). Table 6 summarizes the findings of statistical calculations on the partial test.

Table 6. Partial test results (T Test)

\begin{tabular}{llrrrrr}
\hline & \multicolumn{5}{c}{ Unstandardized Coefficients } & \multicolumn{3}{c}{ Standardized Coefficients } \\
\hline Model & & $\mathrm{B}$ & \multicolumn{1}{c}{ Std. Error } & Beta & \multicolumn{1}{c}{ S } & \multicolumn{1}{c}{ Sig. } \\
\hline 1 & (Constant) & -28644.968 & 178263.150 & & -.161 & -.161 \\
& PAD & .743 & .224 & .148 & 3.314 & .002 \\
& DAU & 1.937 & .335 & .274 & 5.773 & .000 \\
& DAK & -.208 & .644 & -.015 & -.324 & .748 \\
& DBH & 1.311 & .063 & .989 & 20.810 & .000 \\
\hline
\end{tabular}

a. Dependent Variable: Local expenditure

Source: Secondary data processed, 2020

Local Revenue. As can be seen in Table $6, \mathrm{t}$ count $=3.314$ and $\mathrm{t}$ table $(\mathrm{df}=\mathrm{n}-\mathrm{k}-1)=$ 2.01410 , the $t$ count $t$ table is statistically significant at 0.002 , implying that PAD has a positive and substantial influence on local expenditure, fund for General Allocation. As shown in Table $7, \mathrm{t}$ count $=5.773$ and $\mathrm{t}$ table $(\mathrm{df}=\mathrm{n}-\mathrm{k}-1)=2.01410$, the $\mathrm{t}$ count $\mathrm{T}$ table has a substantial influence on local spending of 0.000 , indicating that DAU have a positive and significant effect on local expenditure.

Simultaneous Examination (Test F). The F test is used to assess the influence of many independent factors on the dependent variable concurrently. If sig value 0.05 or $\mathrm{F}$ count $>\mathrm{F}$ table, the F-test is significant, indicating that independent factors have a concurrent influence on the $\mathrm{Y}$ variable. If the sig value is more than 0.05 or the $\mathrm{F}$ count is greater than the $\mathrm{F}$ table, then there is no concurrent impact dependent variable. Table 7 summarizes the findings of the F test.

Table 7. Simultaneous significant test results (Test F)

\begin{tabular}{|c|c|c|c|c|c|}
\hline \multicolumn{6}{|c|}{$\mathrm{ANOVA}^{\mathrm{a}}$} \\
\hline Model & Sum of Squares & $\mathrm{df}$ & Mean Square & $\mathrm{F}$ & Sig. \\
\hline 1 Regression & 66865366440000 & 4 & 16716341610000 & 117.448 & $.000 \mathrm{~b}$ \\
\hline Residual & 6404817015000 & 45 & 142329267000 & & \\
\hline Total & 73270183460000 & 49 & & & \\
\hline
\end{tabular}

a. Dependent variable: Belanja Daerah

b. Predictors: (Constant), DBH, PAD, DAK, DAU

Source: Secondary data processed, 2020

F count $=117.448 \mathrm{f}$ table of 2.57 and a significance level of 0.0000 .05 are shown in Table 7. This indicates that the independent variables of local PAD, DAU, DAK, DBH all have a substantial positive influence on local expenditure. 


\subsection{Discussion}

\subsubsection{Local revenue's impact on local expenditure}

According to the study's findings, local revenue has a coefficient of 3.314 and a significance level of 0.0020 .05 . This exemplifies that, between 2014 and 2018, local revenue has a significant beneficial effect on local expenditure. The findings of this study confirm those of previous research [5], [13], which found that PAD has a substantial beneficial influence on local expenditure with a significance value of 0.000 , which is less than 0.05 [8].

\subsubsection{The impact of DAU on local expenditure}

The coefficient value of general allocation funds in this study is 5.773, with a significance level of 0.0000 .05 . It demonstrates that DAU have a considerable beneficial influence on local expenditure from 2014 to 2018. These findings are corroborated by studies [5] and [13], decided that monies for DAU have a positive and substantial influence on local expenditure, with a significance value of 0.000 being less than 0.05 [8].

\subsubsection{The effect of DAK funds on local expenditure}

According to this study, DAK have a coefficient of -0.324 and a significance level of $0.748>0.05$. It demonstrates that DAK have no discernible influence on local expenditure between 2014-2018. This is consistent with earlier studies done by [6] and [15], which concluded that DAK had no discernible influence on local expenditure when the significance value of 0.58 is larger than 0.05 [8].

\subsubsection{The effect of profit-sharing funds on local expenditure}

Profit-sharing funds are found to have a coefficient of 20,810 and a significant value of $0,0000.05$. It demonstrates that profit-sharing funds have a favorable and considerable influence on local expenditure between 2014-2018. The findings of this study confirm those of [5] and [13], which claimed that profit-sharing funds have a positive and substantial effect on local expenditure when the substantial value is less than 0.000 [8], [15].

4.3.5 The effect of local revenue, general allocation fund, special allocation fund and profit-sharing fund on local expenditure

According to the F test, all PAD, DAU, DAK, DBH have a positive coefficient value of 117.448 and a significance level of 0.000 0.05. Also, have a positive and significant impact on local expenditure between 2014 and 2018.

\section{Conclusion}

This research's result may be summarized as follows. For the years 2014-2018, PAD, DAU, and DBH have a positive and significant influence on local expenditure in districts/cities across 
East Kalimantan Province. Then, from 2014 to 2018, DAK has had no discernible influence on local expenditure in districts/cities throughout East Kalimantan province.

\section{References}

[1] Y. Li, "Regulation Fair Disclosure and the Determinants of Analyst Coverage," J. Financ. Account. vol. 3, no. 6, p. 205, 2015, doi: 10.11648/j.jfa.20150306.15.

[2] M. T. Efendy, "Pengaruh Kompetensi, Independensi, dan Motivasi Terhadap Kualitas Audit Aparat Inspektorat Dalam Pengawasan Keuangan Daerah (The Effect of Competence, Independence, and Motivation on Audit Quality of Inspectorate Officers in Regional Financial Supervision)", J. Ilm. Akunt., pp. 1-109, 2010, doi: 10.1017/CBO9781107415324.004.

[3] La Ode Hasiara; Sudarlan; and Ahyar M. Diah, "Regional government manage-ment strategy in achieving unqualified opinion (UQO) in east Kalimantan Pro-vince, Indonesia,” Int. J. Innov. Creat. Chang., vol. 12, no. 9, pp. 271-282, 2020.

[4] Tentang D. P. Peraturan Pemerintah Republik Indonesia Nomor 55 Tahun 2005, Peraturan Pemerintah Republik Indonesia Nomor 55 Tahun 2005, tentang Dana Perimbangan (Concerning D. P. Government Regulation of Republic of Indonesia Number 55-year 2005, Government Regulation of Republic of Indonesia Number 55 of 2005, on Matching Grant), vol. 46(2), no. Neurofibroma, schwannoma or a hybrid tumor of the peripheral nerve sheath. 2005, p. 7.

[5] K. Waitkus, "Undang-Undang Republik Indonesia Nomor 33 Tahun 2004, tentang Perimbangan Keuangan Antara Pemerintah Pusat dan Pemerintah Daerah (Regulation of Republic of Indonesia Number 33-year 2004, on the Financial Balance between the Central Government and Local government)," no. August, p. 55, 2004, [Online]. Available: http://eprints.uanl.mx/5481/1/1020149995.PDF.

[6] W. J. Haryadi Sarjadi, "SPSS vs Lisrel Sebuah Pengantar Aplikasi Untuk Riset (SPSS vs Lisrel an Introduction to Applications for Research).” Salemba Empat, Jakarta., Jakarta Indonesia, pp. iii-210, 2011.

[7] Peraturan Menteri Dalam Negeri Nomor 13 Tahun 2011, Peraturan Menteri Dalam Negeri Nomor 13 Tahun 2011(Regulation of Minister of domestic Affairs Number 13-year 2011, Regulation of Minister of Domestic Affairs Number 13-year 2011), vol. 11, no. 2. 2011, pp. 10-14.

[8] P. H. Adi, "Hubungan Antara Dana Alokasi Umum, Belanja Modal (The Relationship Between General Allocation Funds and Capital Expenditures), Aspp-15," no. July 2007, pp. 1-27, 2015.

[9] P. Adi, "Kemampuan Keuangan Daerah dalam Era Otonomi dan Relevansinya dengan Pertumbuhan Ekonomi (Studi pada Kabupaten dan Kota se Jawa - Bali) (Regional Financial Capability in Autonomy Era and its Relevance to Economic Growth (Studies at Districts and Cities in Java Bali))," no. 22, pp. 1-19, 2012.

[10] R. Andika Thio Rahman, G. Irianto, and R. Rosidi, "Evaluation of E-Budgeting Implementation in Provincial Government of DKI Jakarta Using CIPP Model Approach,” J. Account. Invest., vol. 20, no. 1, 2019, doi: 10.18196/jai.2001110.

[11] Baihaqi, "Analisis Pengelolaan Keuangan Daerah Dan Kemandirian Daerah Pada Kabupaten Bengkulu Tengah (Analysis of Regional Financial Management and Regional Independence in Central Bengkulu Regency)," Fairness, vol. 2, no. 1, pp. 1-14, 2012.

[12] P. Kemampuan, K. Daerah, P. O. Daerah, D. I. Kabupaten, and H. Utara, "Pengaruh Kemampuan Keuangan Daerah Terhadap Penyelenggaraan Otonomi Daerah Di Kabupaten Halmahera Utara (The Effect of Regional Financial Capabilities on Implementation of Regional Autonomy in North Halmahera Regency)," J. Adm. Publik UNSRAT, vol. 2, no. 044, pp. 1-14, 2016.

[13] S. Dhiyavani, A. Nasir, and S. Paulus, "Pengaruh Kinerja Aparatur Pemerintah Daerah, Pengelolaan Keuangan Daerah, Sistem Pengendalian Internal, dan Implementasi Standar Akuntansi Pemerintah terhadap Penerapan Good Governance (The Effect of Local Government Apparatus Performance, Regional Financial Management, Internal Control Systems, and Implementation of Government 
Accounting Standards on Good Governance Implementation),” J. Online Mhs. Fak. Ekon. Univ. Riau, vol. 4, no. 1, pp. 1859-1872, 2017.

[14] U. Khasanah, S. T, and E. Mardiati, "Coercive Authority and Trust in Tax Authority in Influencing Voluntary Tax Compliance: A Study of Slippery Slope,” J. Account. Invest., vol. 20, no. 1, 2019, doi: 10.18196/jai.2001109.

[15] D. O. Ruspina, "Pengaruh Kinerja Aparatur Pemerintah Daerah, Pengelolaan Keuangan Daerah, Sistem Pengendalian Internal Pemerintah Terhadap Penerapan Good Governance (Studi empiris pada Pemerintah Kota Padang),” J. Akunt., no. September, pp. 1-27, 2013.

[16] W. A. Jogyanto Hartono, "Konsep Aplikasi PLS (Partial Lesquare) Untuk Penelitian Empiris." FakultasIlmu Ekonomi dan Bisnis Universitas Gaja Madah, Yogyakarta, Indonesia., pp. iii-178, 2016.

[17] La Ode Hasiara; Sudarlan; and Ahyar Muhammad Diah, "Managerial Competence in Achieving Unqualified Opinion (UQO) in East Kalimantan Province-Indonesia," SOSHUM J. Sos. dan ..., vol. 9, no. 2, pp. 142-150, 2019. 